\title{
OJAČANJE POVIJESNIH GRAĐEVINA KOMPOZITNIM POLIMERIMA
}

\author{
Martina Španić \\ Sveučilište Josipa Jurja Strossmayera u Osijeku, Građevinski fakultet Osijek, dipl.ing.građ. \\ Marijana Hadzima-Nyarko \\ Sveučilište Josipa Jurja Strossmayera u Osijeku,Građevinski fakultet Osijek, doc.dr.sc. \\ Dragan Morić \\ Sveučilište Josipa Jurja Strossmayera u Osijeku, Građevinski fakultet Osijek, prof.dr.sc.
}

Sažetak: Većina građevina kulturne ili graditeljske baštine su zidane zgrade koje su izgrađene najčešće od kamenih ili opečnih zidnih elemenata povezanih mortom, a zidane su prije postojanja znanja i propisa 0 protupotresnom građenju. Kompleksnost sanacije povijesnih građevina uvjetuje nekompatibilnost tradicionalnih i novih gradiva te poštivanje njihovog izvornog postojanja, zbog čega se ne preporučuje ni uporaba armiranog betona. U radu je opisana inovacijska metoda ojačanja povijesnih građevina tehnikom postavljanja kompozitnih polimera te prednosti navedene tehnike u odnosu na tradicionalne metode ojačanja i njezina primjena na postojećim građevinama.

Ključne riječi: ojačanje, povijesne građevine, kompozitni polimeri

\section{STRENGTHENING OF HISTORICAL BUILDINGS WITH COMPOSITE POLYMERS}

\begin{abstract}
Most buildings of cultural or architectural heritage are masonry buildings constructed mostly of stone or brick walls. Those kinds of buildings were built before the existence of seismic knowledge and regulations. The complex issue of rehabilitation of historic buildings is based on incompatibility of traditional and new materials as well as on the necessity to preserve the original appearance of these buildings. The use of reinforced concrete is not recommended in rehabilitation of historical buildings. This paper will describe the innovative method of reinforcement of historic buildings with composite polymer technology and the advantages of the aforementioned technique compared to some traditional reinforcement methods and its application to existing buildings.
\end{abstract}

Key words: strengthening, historical buildings, composite polymers 


\section{Uvod}

Većinu građevina kulturne ili graditeljske baštine čine zidane zgrade. Najčešće su izvedene od kamenih ili opečnih zidnih elemenata povezanih vapnenim ili vapnenocementim mortom bez armiranja, prije postojanja znanja i propisa o protupotresnom građenju.

Tijekom svoga vijeka, povijesne građevine doživjele su različite dogradnje i nepogode kao što su požari, potresi ili eksplozije. Postojeće zidane zgrade mogu preuzeti djelovanja vertikalnih sila i horizontalnih sila vjetra, koje su znatno manje od očekivanih potresnih sila te in je stoga potrebno ojačati. Kompleksnost sanacije povijesnih građevina uvjetovana je nekompatibilnošću tradicionalnih i novih gradiva. Takva stajališta nisu dokazana, no ipak se smatra da je uporaba betona i armiranog betona nedopustiva.

Postoje dva kruta krajnja pristupa, konzervatorski i konstruktorski. S jedne strane, konzervatorski pristup zasniva se na pretpostavci da je dugovječnost starih građevina sama po sebi dokazana te da intervencija u smislu zadiranja u nosivost iste nije potrebna. $\mathrm{S}$ druge pak strane, stajalište konstruktora jest da sve nosive strukture treba osigurati prema važećim propisima [1]. Ojačanja zgrada moraju se izvesti tako da potres najjačeg intenziteta može uzrokovati oštećenja, ali ne i rušenje zgrade. Vrste postupaka obnove ili ojačanja uključuju zamjenu oštećenih dijelova novim elementima, podebljanje ili ojačanje elemenata i dodavanje novih nosivih zidova. Te metode dodaju značajnu masu građevini, uzrokujući veće inercijske sile u potresu i često potrebu za ojačanjem temelja, kao i dugi prekid funkcije građevina.

U radu je opisana tehnika ojačanja povijesnih građevina postavljanjem kompozitnih polimera, prednosti te tehnike u odnosu na tradicionalne i njezina primjena na postojećim građevinama. U poglavlju 2 sažeto su prikazane tradicionalne tehnike ojačanja zidanih građevina. Osnovne značajke vlaknima ojačanih polimera opisane su u poglavlju 3, a potkrijepljene su rezultatima laboratorijskih eksperimenata provedenima nad konstrukcijskim elementima - stupovima i ziđu, koji su ojačani proizvodima od polimera armiranog vlaknima. Primijenjeno ojačanje kompozitnim materijalima, polimerima armiranih vlaknima na stvarnim zidanim građevinama, opisano je u poglavlju 4. Na osnovi prikazanih rezultata ispitivanja, dan je sažeti zaključak o primjeni tehnike ojačanja povijesnih građevina kompozitnim polimerima te prednostima te tehnike u odnosu na tradicionalne.

\section{Tradicionalne tehnike ojačanja zidanih građevina}

Veliki je izbor različith tradicionalnih tehnika ojačanja zidanih građevina i elemenata kojima im se povećava čvrstoća i/lii duktilnost. lako su mnoge implementirane u potresnoj obnovi, postoji malo informacija i tehničkih smjernica koje bi pomogle inženjerima ocijeniti sposobnosti pojedinih tehnika. Prednosti i nedostatci tradicionalnih tehnika ojačanja prikazani su tablicom 1. Osim toga, ne postoje pouzdane analitičke metode procjene potresne otpornosti obnovljenih konstrukcija [2].

U slučaju kamenih zidanih konstrukcija, kao najpovoljnija tehnika ojačanja pokazalo se injektiranje, dok se za popravljanje i ojačavanje zidanih konstrukcija od cigle mogu upotrijebiti razne tehnologije kao što su: zatvaranje pukotina oštećenih zidova injektiranjem pukotina cementom ili epoksidnom smjesom, nanošenje armiranih cementnih ili epoksidnih obloga na jednu ili obje strane zida, te prednapinjanje zidova. Prvobitna nosivost zida vraća se uobičajenim načinom zatvaranja pukotina cementnom ili epoksidnom smjesom, iako se krutost u većini slučajeva ne može dovesti u prvobitno stanje.

UsvrhuRadi ojačanja uporabljuje se postupak oblaganja. Za nanošenje cementne žbuke ili betonske obloge te za učvršćivanje armature na zid, koriste se razne tehnologije, a rezultati ovise o otpornosti prvobitnog zida. Ako je kvaliteta zida bila loša, otpornost zida može se više nego udvostručiti, dok kod kvalitetnih zidova stupanj poboljšanja nije tako značajan [3]. 
Tablica 1 - Prednosti i nedostatci tradicionalnih tehnika ojačanja [2]

\begin{tabular}{|c|c|c|}
\hline $\begin{array}{l}\text { Tradicionalne tehnike } \\
\text { ojačanja }\end{array}$ & Prednosti & Nedostatci \\
\hline Ferocement & $\begin{array}{l}\text { niski troškovi, jednostavna tehnologija, } \\
\text { ograničeno dodana masa }\end{array}$ & $\begin{array}{l}\text { smanjenje prostora, utjecaj na arhitekturu, } \\
\text { zahtijeva arhitektonsku površinsku obradu, } \\
\text { ograničenja u smislu učinkovitosti i disipacije } \\
\text { energije }\end{array}$ \\
\hline Ojačana žbuka & $\begin{array}{l}\text { jednostavna tehnologija, ograničeno } \\
\text { dodana masa }\end{array}$ & $\begin{array}{l}\text { smanjenje prostora, utjecaj na arhitekturu, } \\
\text { zahtijeva arhitektonsku površinsku obradu }\end{array}$ \\
\hline Mlazni beton - torketiranje & $\begin{array}{l}\text { značajno poboljšanje u smislu disipacije } \\
\text { energije, velik prirast bočne otpornosti }\end{array}$ & $\begin{array}{l}\text { smanjenje prostora, utjecaj na arhitekturu, } \\
\text { zahtijeva arhitektonsku površinsku obradu, } \\
\text { značajno povećanje mase, }\end{array}$ \\
\hline Injektiranje & $\begin{array}{l}\text { nema dodane mase, neremećenje } \\
\text { funkcije zgrade, nema smanjenja } \\
\text { prostora, ne utječe na arhitekturu }\end{array}$ & $\begin{array}{l}\text { epoksidni kit stvara zone s različitim krutostima i } \\
\text { čvrstoćama, velika cijena epoksidnog kita, } \\
\text { zanemarivi prirast bočne otpornosti pri korištenju } \\
\text { ispuna na bazi cementa }\end{array}$ \\
\hline Vanjsko ojačanje & $\begin{array}{l}\text { sprječava rušenje, velik prirast bočne } \\
\text { otpornosti, poboljšava duktilnost i } \\
\text { disipaciju energije }\end{array}$ & $\begin{array}{l}\text { korozija, značajno povećanje mase, } \\
\text { nemogućnost korištenja prostora za vrijeme } \\
\text { zahvata, zahtijeva arhitektonsku površinsku } \\
\text { obradu }\end{array}$ \\
\hline Omeđeno ziđe & $\begin{array}{l}\text { sprječava rušenje, poboljšava duktilnost } \\
\text { i disipaciju energije }\end{array}$ & $\begin{array}{l}\text { zahtjevna primjena, ograničeni učinak u smislu } \\
\text { bočne otpornosti, nemogućnost korištenja } \\
\text { prostora za vrijeme zahvata, zahtijeva } \\
\text { arhitektonsku površinsku obradu }\end{array}$ \\
\hline Prednapinjanje & $\begin{array}{l}\text { nema dodane mase, neremećenje } \\
\text { funkcije zgrade, }\end{array}$ & veliki gubitci, sustav sidara, potencijalna korozija \\
\hline Središnja jezgra & $\begin{array}{l}\text { nema smanjenja prostora, neremećenje } \\
\text { funkcije zgrade, ne utječe na } \\
\text { arhitekturu }\end{array}$ & stvaranje zona s različitim krutostima i čvrstoćom \\
\hline
\end{tabular}

\section{Kompozitni polimeri}

Vlaknima ojačani polimeri - PAV (engl. FRP - fibre reinforced polymers) predstavljaju kompozitni materijal razvijen tijekom 1940-tih godina za vojne svrhe i primjenu u zrakoplovstvu. Unatoč ranom razvoju istraživanja primjene PAV kao armature u betonskim elementima, komercijalna primjena proizvoda započinje tek u kasnim 70-tim godinama. Vlaknima ojačani polimeri uspješno se koriste u raznovrsne svrhe: paneli za ispun, cijevi pod pritiskom, rezervoari, krovovi itd. U Njemačkoj je 1986. sagrađen prvi nadvožnjak koristeći PAV [4]. Osim što se za nove konstrukcije rabe kao armaturne šipke, natege za prednapinjanje ili trake, materijali od PAV-a se također rabe za sanacije i nadogradnje postojećih građevina u obliku ojačanja.

PAV je kompozitni materijal sastavljen od polimerne matrice armirane organskim ili anorganskim vlaknima određenih omjera duljine i debljine, a koja su međusobno povezana smolama. Najbolja je smola epoksidna smola [5]. Matrica, obično napravljena od poliestera, epoksija ili najlona, povezuje i štiti vlakna od oštećenja te prenosi naprezanja između vlakanimaa. Vlakna se mogu uvesti u polimernu matricu u uvjetima jakog tlaka u određeni položaj i smjer. Općenito su organizirani u laminatnu strukturu, tako da svaka lamela sadrži raspoređena vlakna. Vlakna mogu biti staklena, aramidna i ugljična, te se i u građevinarstvu koriste polimeri armirani staklenim vlaknima (PASV) (engl. glass-fiber reinforced plastic - GFRP), ugljičnim vlaknima (PAUV) (engl. carbon fiber reinforced plastic - CFRP) i aramidnim vlaknima (PAAV) (engl. aramid fiber reinforced plastic - AFRP). Ovisno 0 vrsti vlakana, vrsti vezne smole i obliku ${ }_{2}$ na tržištu se javljaju u velikom broju različitih tipova, a upotrebljavaju se za izradu šipki i žica, natega i tankostijenih proizvoda (trake, plahte, lamele) [4].

Karakteristike kompozitnog materijala izravno ovise o njegovim komponentama: vlaknima, sustavu matrice, području međusloja i orijentaciji vlakana.

Velika vlačna čvrstoća u smjeru vlakana, otpornost na koroziju, mala težina, mala toplinska i električna provodljivost (staklena i aramidna vlakna), prednosti su PAV-a u odnosu na armaturni čelik [6]. 
Proizvodi od PAV-a kao nedostatke imaju linearno elastično ponašanje do sloma, te veliku razliku u svojstvima uzduž i poprijeko na smjer pružanja vlakana. Glavni nedostatak jest da takvi proizvodi nisu duktilni, tj. nema izrazitog popuštanja materijala, kod određenog naprezanja, kao kod čelika [7]. Usporedba mehaničkih svojstava (u uzdužnom smjeru) prikazana je tablicom 2.

Tablica 2 - Usporedba mehaničkih svojstava PAV i armaturnog čelika [4]

\begin{tabular}{|c|c|c|c|c|c|c|}
\hline & $\begin{array}{c}\text { Čelična } \\
\text { arm. šipka }\end{array}$ & Čelični kabel & PASV šipka & PASV kabel & PAUV šipka & PAUV kabel \\
\hline $\begin{array}{l}\text { Vlačna čvrstoća, } \\
\text { MPa } \\
\text { (ksi) }\end{array}$ & $\begin{array}{c}483-650 \\
70-100\end{array}$ & $\begin{array}{c}1379-1862 \\
200-270\end{array}$ & $\begin{array}{c}517-1207 \\
75-175\end{array}$ & $\begin{array}{c}1379-1724 \\
200-250\end{array}$ & $\begin{array}{c}165-2410 \\
240-350\end{array}$ & $\begin{array}{c}1200-2068 \\
170-300\end{array}$ \\
\hline $\begin{array}{l}\text { Granica } \\
\text { popuštanja, MPa } \\
\text { (ksi) }\end{array}$ & $\begin{array}{c}276-414 \\
40-60\end{array}$ & $\begin{array}{c}1034-1396 \\
150-203\end{array}$ & \multicolumn{4}{|c|}{ Ne primjenjuje se } \\
\hline $\begin{array}{l}\text { Modul elastičnosti } \\
\mathrm{GPa}(\mathrm{ksi})\end{array}$ & $\begin{array}{c}200 \\
29.000\end{array}$ & $\begin{array}{c}186-200 \\
27.000-29.000\end{array}$ & $\begin{array}{c}41-55 \\
6000-8000\end{array}$ & $\begin{array}{c}48-62 \\
7000-9000\end{array}$ & $\begin{array}{c}152-165 \\
22.000-24.000\end{array}$ & $\begin{array}{c}50-74 \\
70.000-11.000\end{array}$ \\
\hline $\begin{array}{l}\text { Granično } \\
\text { izduženje } \\
\mathrm{mm} / \mathrm{mm}\end{array}$ & $>0,10$ & $>0 / 04$ & $0,035-0,05$ & $0,03-0,045$ & $0,01-0,015$ & $0,02-0,026$ \\
\hline $\begin{array}{l}\text { Tlačna čvrstoća, } \\
\mathrm{MPa} \\
\text { (ksi) }\end{array}$ & $\begin{array}{c}276-414 \\
40-60\end{array}$ & 1 & $\begin{array}{c}310-482 \\
45-70\end{array}$ & 1 & 1 & I \\
\hline $\begin{array}{l}\text { Koef. toplinske } \\
\text { rastezljivosti } \\
\left(10^{-6} / \mathrm{C}\right)\left(10^{-6} / \mathrm{F}\right)\end{array}$ & $\begin{array}{l}11,7 \\
6,5 \\
\end{array}$ & $\begin{array}{l}11,7 \\
6,5 \\
\end{array}$ & $\begin{array}{l}9,9 \\
5,5 \\
\end{array}$ & $\begin{array}{l}9,9 \\
5,5\end{array}$ & $\begin{array}{l}0,0 \\
0,0\end{array}$ & $\begin{array}{l}-1,0 \\
-0,5\end{array}$ \\
\hline Specifična težina & 7,9 & 7,9 & $1,5-2,0$ & 2,4 & $1,5-1,6$ & 1,25 \\
\hline
\end{tabular}

Povećanje čvrstoće, krutosti i duktilnosti zidanih konstrukcijskih elemenata - stupova i zidova ojačanih PAV plahtama ili šipkama ${ }_{2}$ potvrđeno je rezultatima provedenih laboratorijskih eksperimenata opisanih u sljedećim potpoglavljima.

\subsection{Ispitivanje stupova ojačanih polimerima s ugljičnim vlaknima}

U radu [8] opisani su rezultati ispitivanja 18 stupova visine $1,2 \mathrm{~m} \mathrm{~s}$ tri različita poprečna presjeka i dva različita tipa opeke: uobičajenom opekom pravokutnih uglova i opekom zaobljenih uglova. Trinaest stupova bilo je kvadratnog te četiri stupa kružnog poprečnog presjeka (jedan je stup podbacio pri početnom ispitivanju). Kružni poprečni presjek dobiven je izvedbom betonskog plašta po obodu stupa. Svaki je stup prvo bio osno opterećen do pojave pukotina u zidnom elementu, zatim je omatan polimernim plahtama ojačanim ugljičnim vlaknima duž čitave visine, te ponovno osno opterećen od vršnog opterećenja neojačanog stupa do sloma ojačanog stupa. Polimerni omot stupa ostao je u osnovi neoštećen u gotovo svim slučajevima. Na uglovima dvaju stupova primijećeni su rascjepi u polimernom omotu duljine $5-10 \mathrm{~mm}$.

Rezultati ispitivanja neojačanih i ojačanih kvadratnih i okruglih stupova prikazani su u tablici 3. Povećanje u nosivosti, od vrijednosti nosivosti pri pojavi pukotina za neomotane kvadratne stupove do vrijednosti nosivosti pri slomu za kvadratne stupove ojačane polimernim trakama ${ }_{2}$ kreće se prosječno $34 \%$, dok je za okrugle stupove prosječna vrijednost povećanja nosivosti $178 \%$. Navedeni rezultati ukazuju na učinkovitost tehnike omatanja zidanih stupova polimernim plahtama uporadi ojačanjąu oštećenih stupova [8]. 


\section{Tablica 3 - Rezultati ispitivanja stupova [8]}

\begin{tabular}{|c|c|c|c|c|}
\hline $\begin{array}{c}\text { Oblik poprečnog } \\
\text { presjeka }\end{array}$ & $\begin{array}{c}\text { Veličina } \\
\text { presjeka } \\
\text { [mm] }\end{array}$ & $\begin{array}{c}\text { Prosječno opterećenje pri } \\
\text { pojavi pukotina kod } \\
\text { neomotanih stupova [MN] }\end{array}$ & $\begin{array}{c}\text { Prosječna čvrstoća } \\
\text { ojačanih stupova [MN] }\end{array}$ & $\begin{array}{c}\text { Povećanje } \\
\text { nosivosti } \\
\text { [\%] }\end{array}$ \\
\hline \multirow{2}{*}{$290 \times 290$} & 2,1 & 2,6 & 24 \\
\cline { 2 - 6 } & $390 \times 390$ & 3,3 & 4,7 & 42 \\
\cline { 2 - 6 } & \multirow{2}{*}{$490 \times 490$} & 4,2 & 5,7 & 36 \\
\hline
\end{tabular}

\subsection{Ispitivanje ziđa ojačanog polimerima sa staklenim vlaknima}

$\mathrm{U}$ radu [9] provedeno je ispitivanje nearmiranog ziđa podvrgnutog cikličkom opterećenju izvan ravnine. Konstruirano je sedam tankih zidova od opeke u mjerilu 1:2 koristeći pune glinene opeke $(49 \times 38 \times 102 \mathrm{~mm}) \mathrm{za}$ popločavanje, od kojih je šest zidova bilo jednoslojnih, a jedan je dvoslojan. Jednoslojni zidovi su ojačani trima vertikalnim trakama od staklene tkanine povezane na sjevernoj i južnoj površini zida. Dvoslojni zid je bio ojačan samo na sjevernoj strani. Kompozitne su trake lijepljene epoksidnom smolom ${ }_{2}$ postupkom mokrog polaganja. Zidovi su bili ispitivani u čeličnim tlačnim okvirima, a uzorci su bili jednostavno pridržani duž gornjeg i donjeg brida, dok su dvije vertikalne strane bile slobodne. Na vrhu je stvoren pomični ležaj, tj. dopušteni su vertikalni pomaci.

Prisustvo kompozitnih traka značajno je povećalo nosivost zidova (slika 1). Uzorci su se odupirali opterećenju, koje se kretalo od 5 do 30 puta težine zida. Ova velika opterećenja do sloma, znatno veća nego kod tipičnog nearmiranog ziđa, mogu se očekivati tijekom potresa. Slike također upućuju da je granično opterećenje proporcionalno s omjerom ojačanja. Omatanje kompozitima pretvorilo je krhke zidove u vrlo čvrste i duktilne elemente [9].
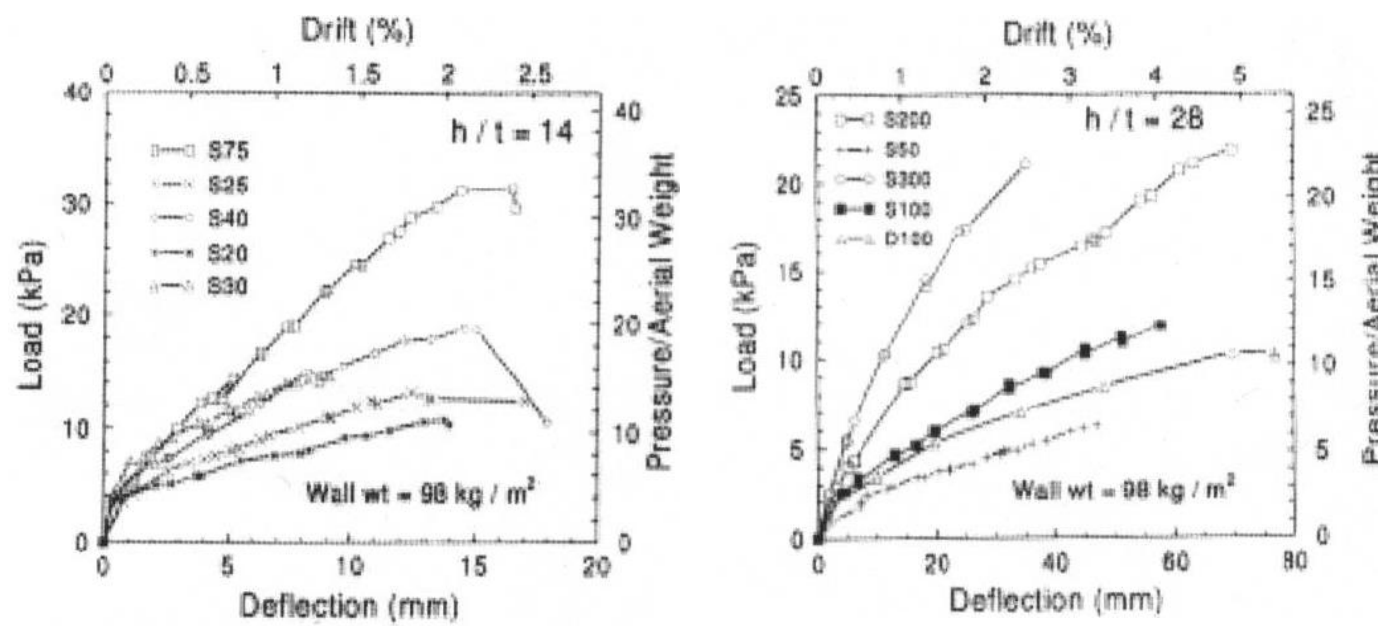

Slika 1 - Ovojnice opterećenje-progib za kratke i za vitke zidove [9] 


\subsection{Ispitivanje ziđa ojačanih armiranjem i kompozitnim polimerima}

U Hrvatskoj su 2007. u laboratoriju Zavoda za tehničku mehaniku Građevinskog fakulteta u Zagrebu izvedena ispitivanja- kako bi se utvrdila povećanja nosivosti i duktilnosti ojačanog ziđa, na posmično opterećenje na uzorcima zidanih zidova od pune opeke, čija su svojstva detaljno opisana i prikazana u radu [10]. Uzorci su bili dimenzija $103 \times 12 \times 106 \mathrm{~cm}$ te su ispitani pri pet različitih tipova ojačanja (slika 2). Tri uzorka bila su ispitana neojačana (slika 2a), tejedan uzorak je armiran čeličnim šipkama (slika 2b) i jedan šipkama od PASV-a (slika 2c). Šipke su u armiranom ziđu bile postavljene po jedna u svaku drugu sljubnicu morta. Dva ispitana uzorka bila su ojačana postavljanjem traka od staklenih vlakana u horizontalnom smjeru i dijagonalno (slika 2d), te dva postavljenim trakama u horizontalnom i vertikalnom smjeru (slika 2e). Svi uzorci bili su ispitani na horizontalno promjenjivo opterećenje i konstantno vertikalno opterećenje.
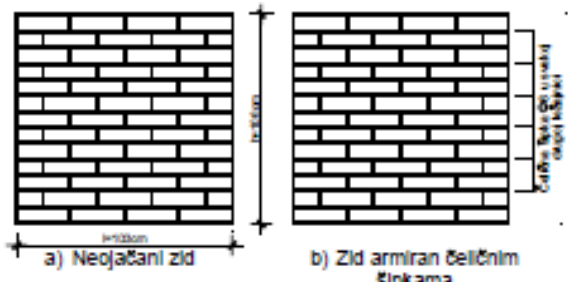

sipkama

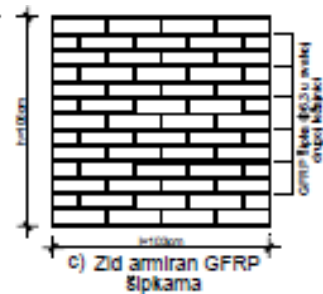

glpkama

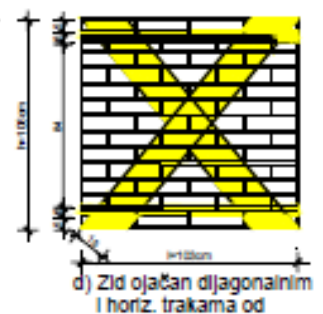
Thoriz. trakama od

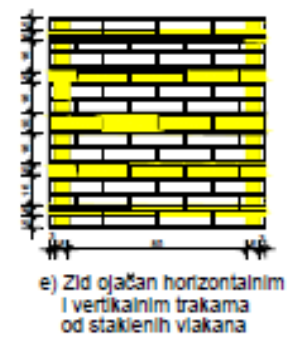

Slika 2 - Vrste ispitivanih zidnih uzoraka [10]

Rezultati ispitivanja, prikazani slikama 3 i 4, pokazali su znatno povećanje nosivosti na horizontalno opterećenje pri svim tipovima ojačanja. Najveće povećanje od $86 \%$ utvrđeno je kod uzorka ojačanog horizontalnim i vertikalnim trakama. Isti je uzorak pokazao i najveće povećanje ekvivalentne vlačne čvrstoće $(116 \%)$ u odnosu na neojačani uzorak. Slične rezultate pokazali su i uzorci s dijagonalno postavljenim trakama: povećanje od $83,5 \%$ kod horizontalnog opterećenja i 109,2\% povećanja ekvivalentne vlačne čvrstoće. Armirani uzorci također su postigli značajna povećanja, ali je kod ovih uzoraka slom nastupio nastankom pukotine u smjeru tlačne dijagonale, što kod uzoraka ojačanih trakama nije bio slučaj. Uzorci ojačani trakama su i nakon sloma ostali cjeloviti, kompaktni [10].

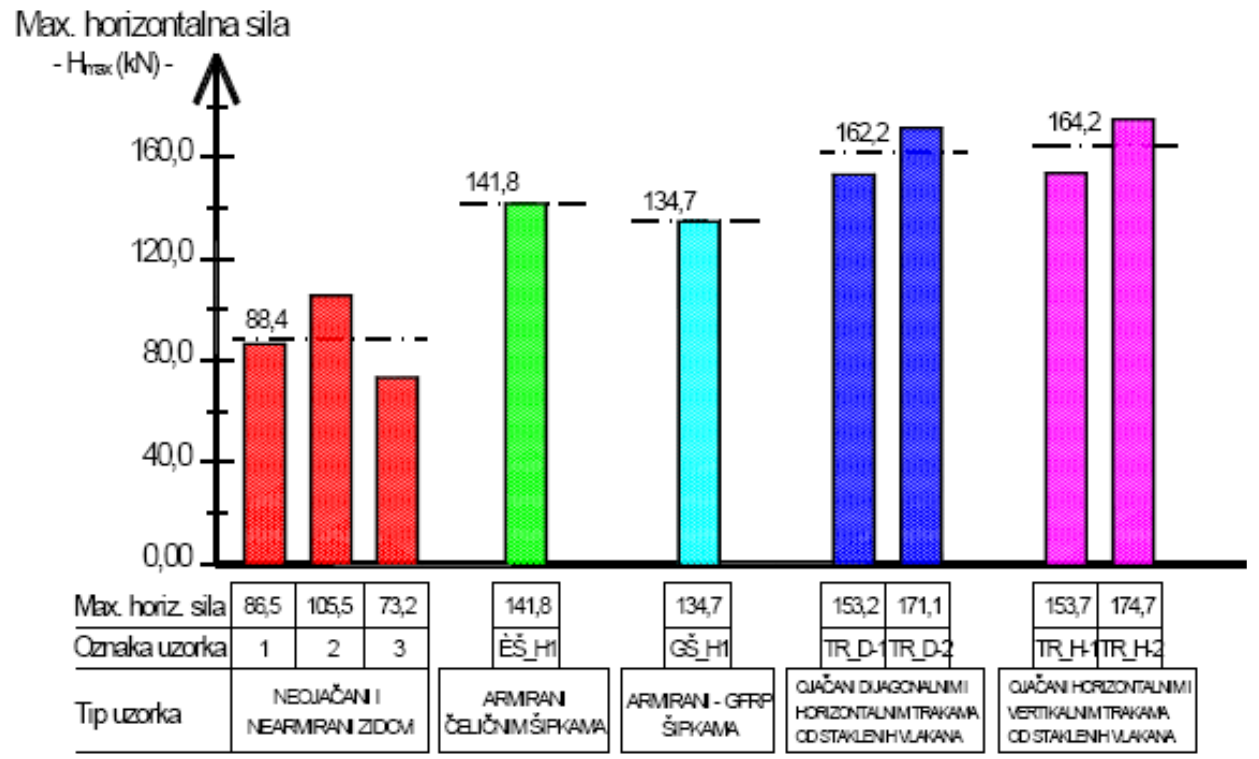

Slika 3 - Grafički prikaz maksimalnih horizontalnih sila pojedinih uzoraka i prosječnih vrijednosti [10] 


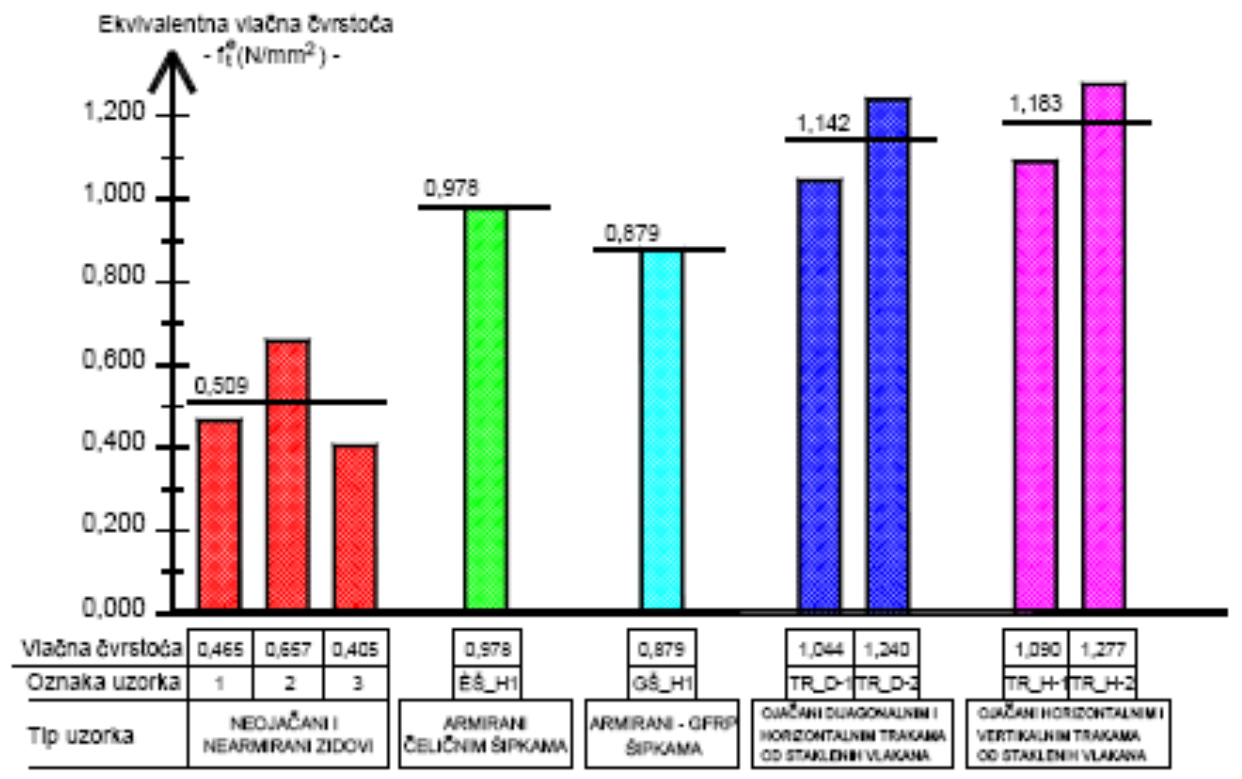

Slika 4 - Grafički prikaz ekvivalentne vlačne čvrstoće ziđa i njihovih prosječnih vrijednosti [10]

Prikazanim je rezultatima pokusa ojačanja stupova i ziđa potvrđeno povećanje čvrstoće, krutosti i duktilnosti. PAV tkanine ${ }_{2}$ debele nekoliko milimetara ${ }_{2}$ mogu se brzo postaviti. Stoga nije iznenađujuća činjenica da su PAV materijali privlačniji u ojačanju i popravku zahvaljujući njihovoj maloj masi i lakoći primjene.

\section{In-situ ispitivanja ojačanja povijesnih građevina kompozitnim polimerima}

\subsection{Građevina Elmi-Pandolfi (Foligno, Italija)}

Građevina Elmi-Pandolfi nalazi se u povijesnom centru Foligna u Italiji. Kao kompleks različitih konstrukcijskih jezgri nastalih mijenjanjem tijekom vremena ${ }_{1}$ zauzima velikị dio povijesnog centra. Stalni obris građevina poprima tijekom 17. Stoljeća ${ }_{1}$ kada postaje aristokratska obiteljska građevina s prostranim hodnicima, odajama za obitelj, posebnim odajama za sluge i za poslovanje. Tijekom potresa 1997. građevina je pretrpjela znatna oštećenja te je nakon tih događanja obnovljena, uključujući protupotresna ojačanja [11].

Zidovi pročelja i svod salona navedene građevine ojačani su postavljanjem kompozitnih polimernih traka te su izvršena dinamička in-situ ispitivanja svoda. Protupotresno ojačanje zidova pročelja izvedeno je postavljanjem tri horizontalna pojasa polimera armiranih ugljičnim vlaknima i dodatnihm vertikalnihm pojasevaima, čime je ziđu omogućeno preuzimanje znatnog vlačnog naprezanja $a_{1}$ a osigurano je i ôd sloma izvan ravnine, koji je uobičajen za povijesne građevine i njihova pročelja zbog nedostatka veza među zidovima [11].

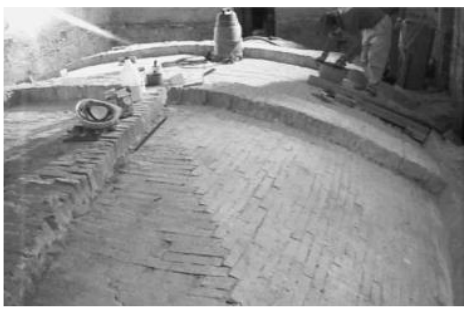

a)

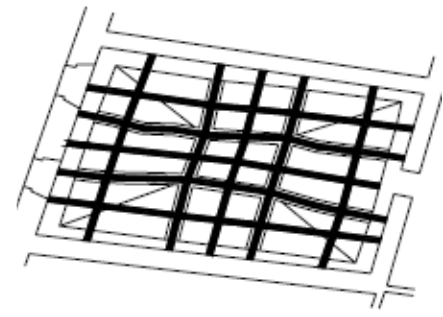

b)

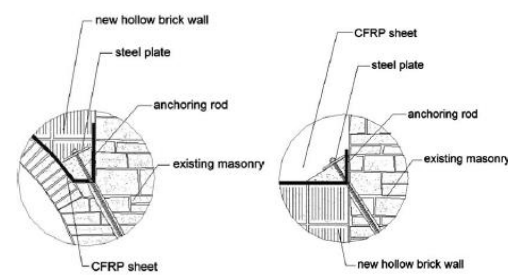

c)

Slika 5 - a) Neojačani svod, b) shematski prikaz pozicija polimernih pojaseva, c) detalji spoja [11] 
Svod salona ojačan je tehnikom postavljanja polimernih traka s ugljičnim vlaknima na ekstradosu. Prije postavljanja kompozitnih traka ${ }_{2}$ izvršena je potrebna priprema svoda (slika 5a). Prvo je uklonjen materijal ispuna sve do oslanjanja svoda na vanjski zid, tijekom čega je pronađeno ješest lukova od pune opeke koji su služili kao ojačanje svoda. Čišćenje površine svoda izvedeno je pjeskarenjem i otapalima na bazi vode. Zbog osjetljivosti kompozitnih polimera na nepravilnosti površine polaganja ${ }_{1}$ izveden je ležajni pojas izveden premazom sloja epoksidnog kita, a za završni je sloj nanesena epoksidna smola. Slika $5 b$ prikazuje shemu pozicija polimernih traka na svodu [11].

Na slici 5c prikazan je detalj spoja kompozitnog polimera i vanjskog zida prostorije. Spoj je izveden tako da je malo kita naneseno na postavljeni polimer koji je pomoću čelične ploče i klina učvršćen u postojeće ziđe. Nakon završetka ojačanja, materijal ispuna zamijenjen je šupljom opekom te su spriječeni neki mehanizmi sloma [11].

Glavni uzrok sloma ojačanog i neojačanog svoda uzrokuje-je pojava pukotina. Prije nastajanja pukotine u svodu $_{2}$ nosivost neojačanog svoda određena je vlačnom čvrstoćom ziđa. Jednom puknut, svod se mijenja te sei ponaša se kao sustav lukova. Najčešći mehanizam sloma svoda jest nastajanje cilindričnog zgloba. Ojačanjem polimernim pojasevima u ekstradosu luka moguće je spriječiti cilindrični zglob i neke mehanizme sloma [11].

Svod salona je dinamički ispitan prije i nakon ojačanja te su dobiveni rezultati za tri različita slučaja: neojačani svod, svod ojačan kompozitnim polimerima, te svod ojačan polimernim materijalima i zidom od šuplje opeke. Analizirani su pomaci u zadanim točkama te frekvencija svoda. Pomaci su mjereni laserskim vibrometrom u različitim točkama: točke 2 i 3 na boku i točka 4 na kruni svoda. Rezultati ispitivanja prikazani su tablicom 4.

Tablica 4 - Prikaz najvećih pomaka u točkama mjerenja prije i nakon ojačanja [11]

\begin{tabular}{|l|c|c|c|}
\hline & \multicolumn{3}{|c|}{ Najveći pomaci u mjernim točkama (mm) } \\
\hline Tehnika ojačanja & Točka mjerenja & $\begin{array}{c}\text { Točka mjerenja } \\
\mathbf{2}\end{array}$ & $\begin{array}{c}\text { Točka mjerenja } \\
\mathbf{4}\end{array}$ \\
\hline Bez ojačanja & $\mathbf{0 , 0 9 3 0}$ & $\mathbf{0 , 0 2 5 0}$ & $\mathbf{0 , 0 2 4 0}$ \\
\hline Polimeri s ugljičnim vlaknima & $\mathbf{0 , 0 0 8 7}$ & $\mathbf{0 , 0 1 4 0}$ & $\mathbf{0 , 0 2 8 0}$ \\
\hline $\begin{array}{l}\text { Polimeri s ugljičnim vlaknima i zid } \\
\text { od šuplje opeke }\end{array}$ & $\mathbf{0 , 0 0 6 7}$ & $\mathbf{0 , 0 0 5 5}$ & $\mathbf{0 , 0 0 6 3}$ \\
\hline
\end{tabular}

Nakon ojačanja polimerima ${ }_{2}$ mjerenja su pokazala smanjenje pomaka u odnosu na neojačano stanje. Daljnje smanjenje pomaka zabilježeno je nakon što je konstrukcija bila dodatno ojačana zidom od šuplje opeke. Prikazani rezultati u točki 4 pokazuju povećanje pomaka nakon ojačanja.; Ttakvo ponašanje pripisuje se pukotini koja je zabilježena u svodu između točaka 3 i 4 , a koja je naknadno sanirana. Rezultati ispitivanja su pokazali pozitivan učinak ojačanja i zamjetnu redukciju vršnih vrijednosti pomaka [11].

\subsection{Povijesne građevine na području gradova Foligno i Sellano}

U sklopu znanstvenog istraživanja Laboratorija za protupotresno istraživanje u Italiji, provedeno je ispitivanje sedam povijesnih građevina od strane Laboratorija za protupotresno istraživanje [12]. Građevine su odabrane za ispitivanje zbog sličnih značajki ziđa: teksture, materijala te tipova morta. Teksture ziđa prikazane su slikom 6. Petnaest je panela za ispitivanje izrezano je iz sljedećih građevina:

- Vescia i Belfiore građevine - školske ustanove izgrađene početkom prošlog stoljeća sadržajno sličnim tehnikama i materijalima. U oba slučaja debljina ziđa je približno $48 \mathrm{~cm}$. Ziđe je zidano krečnjačkim kamenom koji je grubo sječen, te opekom. Ziđe Vescia i prvog kata Belfiore građevine dvoslojno je kameno ziđe od krečnjačkog kamena čiji su slojevi povezani redovima pune opeke koji se ponavljaju u intervalima od jedan metar (slika 6b). Ziđe drugog kata građevine Belfiore je jednoslojno ziđe od pune opeke (slika 6a).

- Soligno građevina je izdvojena kamena seoska kuća iz 19. stoljeća građena pretežno sitnijim kamenom i slabim vapnenim mortom ${ }_{2}$ teksture prikazane slikom $6 \mathrm{c}$.

- Ponte Postignano građevina zidana je krečnjačkim kamenom, traventinom i vapnenim mortom (slika 6d). 


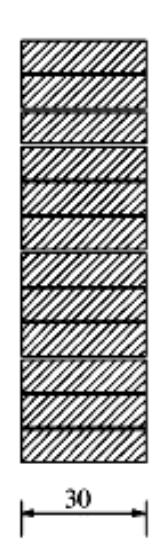

a)

Belfiore, 2nd Floor

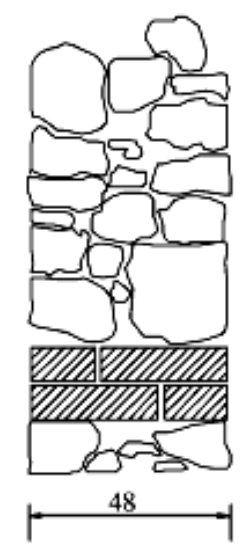

b)

Belfiore 1st floor

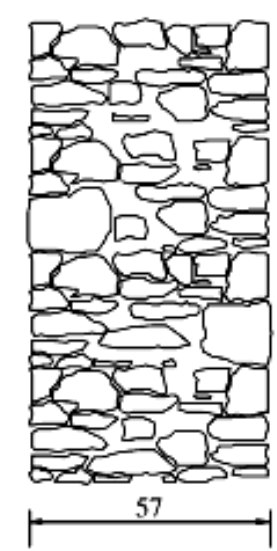

c)

\section{Slika 6 - Tekstura ziđa pojedinih ispitanih građevina [12]}

Tijekom prikazanog istraživanja [12] korištene su tradicionalne (injektiranje) i inovativne tehnike protupotresnog ojačanja (polaganje polimernih traka ojačanih ugljičnim i staklenim vlaknima). Ispitivani su paneli koji su izolirani iz postojećeg ziđa rezanjem dijamantnom žicom kako bi ostali neporemećeni u dvije različite dimenzije. Nakon što su izrezani, paneli su odvojeni od ostatka ziđa, osim na svojim donjim horizontalnim rubovima kako je prikazano slikom 7.

Injektiranje je trenutačno najčešće korištena tehnika protupotresnog ojačanja zidanih konstrukcija. Zasniva se na ispunjavanju pora i pukotina injektiranjem novog ispuna kako bi se ostvario ponovni kontinuitet između opeke i morta prožimanjem šupljina u ziđu. Odabir ispuna za injektiranje ovisi o tipu ziđa, njegovoj teksturi i materijalima i usko je povezan s učinkovitošću tehnike. Tehnika injektiranja koristi se za nadogradnju protupotresne otpornosti konstrukcijskih elemenata i za povećanje čvrstoće elementa na djelovanje statičkog opterećenja. Za ispun je korišten vapneni mort ${ }_{2}$ jer je kompatibilan s postojećim materijalima ziđa (kamenom, opekom i postojećim mortom). Bušotine su načinjene $s$ obje strane panela, približno deset bušotina po kvadratnom metru. Injektiranje je izvršeno pri tlaku od jedne atmosfere, samo s jedne strane panela na 15 do 20 \% bušotina, dok su ostale korištene za kontrolu distribucije ispuna unutar panela [12].

Tehnika ojačanja ziđa kompozitnim polimerima odabrana je za povijesne građevine zbog svoje neagresivnosti, nemasivnosti te mogućnosti preinake. Ispitivanjem se željelo potvrditi učinkovitost polimera pri preuzimanju vlačnog naprezanja uzrokovanog potresom. Paneli su ojačani polimernim trakama s obje strane (slika 7).
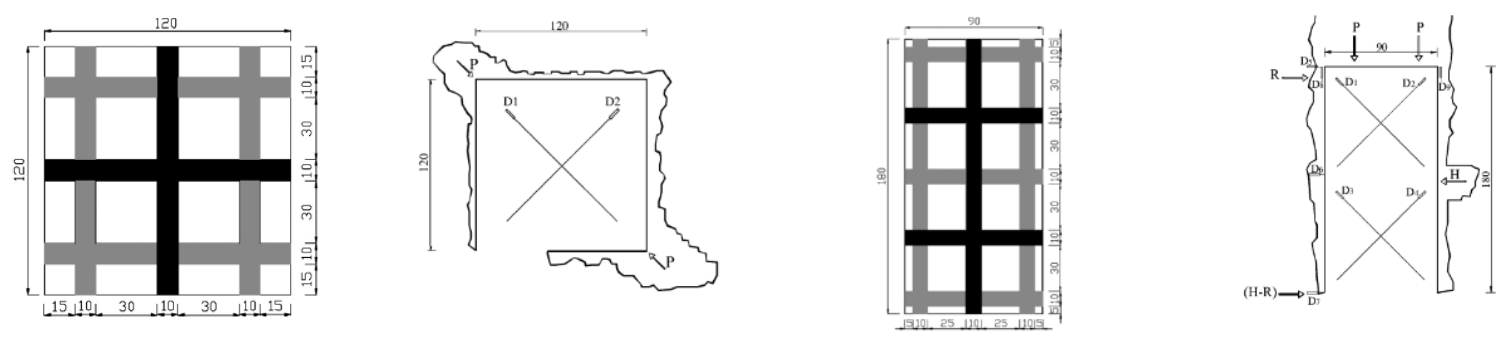

\section{Slika 7 - Shematski prikaz postavljanja polimernih traka na ispitivane panele $s$ obje strane istog $i$ shematski prikaz izrezanih panela te sila tijekom ispitivanja [12]}

Radi boljeg prianjanja polimernih traka, potrebno ih je postaviti na zadovoljavajuće ravnu površinu. Zbog nepravilne površine kamenog ziđa nastale uklanjanjem prvobitne žbuke, na panel je nanesen sloj cementnog morta debljine 4 do $8 \mathrm{~mm}$ prije postavljanja polimera. Tijekom ispitivanja došlo je do popuštanja između sloja novog morta i ziđa te je isti zamijenjen tanjim slojem epoksidnog kita debljine 2 do $4 \mathrm{~mm}$. Epoksidni kit pokazao je 
bolje prianjanje s postojećim ziđem, a time i iskoristivost polimernih traka koje se tijekom daljnjih ispitivanja nisu odvojile od panela [12].

Paneli kvadratnog presjeka dimenzija 120x120 cm ispitivani su na dijagonalni tlak, a pravokutni paneli dimenzija 180x90 cm na tlak i smicanje (slika 7). Ispitivanja su prvo izvršena na neojačanim panelima kako bi se utvrdile početne vrijednosti, te potom na ojačanim panelima za različite slučajeve ojačanja i građevina [12].

\subsubsection{Ispitivanje na smicanje}

Šest panela pozicioniranih po dva na građevinama Belfiore, Vescia i Ponte Postignano, ispitano je na smicanje. Paneli su ispitani bez ojačanja, ojačani injektiranjem i kompozitnim polimernim trakama, kako je prikazano tablicom 5. Rezultati ispitivanja pokazali su da paneli ojačani polimerima imaju $55 \%$ veću posmičnu čvrstoću $\left(\mathrm{T}_{\mathrm{k}}\right)$ od neojačanog panela, bez obzira na to jesu li polimeri s ugljičnim ili staklenim vlaknima. Prilikom ovih ispitivanja slom je nastupio u trenutku kada se novonaneseni sloj cementnog morta, na koji je bila položena polimerna traka, odvojio od panela. Zbog ovakvog tipa sloma ispitivanih panela nije pokazana znatna razlika u čvrstoći između ojačanja polimerima s ugljičnim vlaknima i onih sa staklenim, ali je ukazano na slabosti prianjanja između morta i panela. Prilikom kasnijih ispitivanja ${ }_{2}$ polimerne trake postavljane su na sloj epoksidnog kita [12].

Tablica 5 - Rezultati ispitivanja panela na smicanje [12]

\begin{tabular}{|l|l|c|c|c|c|c|c|}
\hline \multicolumn{1}{|c|}{ Panel građevine } & Tehnika ojačanja & $\begin{array}{c}\text { Širina } \\
(\mathbf{c m})\end{array}$ & $\begin{array}{c}\mathbf{H}_{\max } \\
(\mathbf{k N})\end{array}$ & $\begin{array}{c}\mathbf{T}_{\max } \\
(\mathbf{M P a})\end{array}$ & $\begin{array}{c}\mathbf{G}(\mathbf{M P a}) \\
\text { Shema 1 }\end{array}$ & $\begin{array}{c}\mathbf{G}(\mathrm{MPa}) \\
\text { Shema 2 }\end{array}$ & $\mathbf{T k}_{\mathbf{k}}(\mathbf{M P a})$ \\
\hline \hline Belfiore & Bez ojačanja & 48 & 180,70 & 0,224 & 546 & 328 & 0,130 \\
\hline Belfiore & $\begin{array}{l}\text { Polimeri s ugljičnim } \\
\text { vlaknima }\end{array}$ & 48 & 241,40 & 0,352 & 467 & 771 & 0,262 \\
\hline Vescia & $\begin{array}{l}\text { Polimeri sa } \\
\text { staklenim vlaknima }\end{array}$ & 48 & 231,30 & 0,334 & 245 & 249 & 0,245 \\
\hline Vescia & Injektiranje & 48 & 161,30 & 0,237 & 450 & 308 & 0,149 \\
\hline Ponte Postignano & Bez ojačanja & 48 & 100,40 & 0,172 & 216 & 203 & 0,136 \\
\hline Ponte Postignano & Injektiranje & 48 & 266,30 & 0,465 & 645 & 598 & 0,375 \\
\hline
\end{tabular}

Panel ojačan injektiranjem, u slučaju Vescia građevine, nije pokazao značajno povećanje posmične čvrstoće u odnosu na sličan neojačani panel, dok je kod Ponte Postignano građevine pokazao značajno povećanje (tablica 5). Ovakvi rezultati pokazuju da tehnika injektiranja može biti učinkovita kao tehnika za obnovu, ali njezino usvajanje na neoštećenim konstrukcijama zahtijeva prethodnu pažljivu analizu teksture i značajki ziđa kako bi se utvrdilo može li se punilo pravilno distribuirati.

\subsubsection{Ispitivanja dijagonalnim tlakom}

Paneli građevine Belfiore koji su ispitivani na dijagonalni tlak bili su od pune opeke, od kojih je jedan bio ojačan polimernim trakama s ugljičnim vlaknima, a drugi neojačan. Ispitivanje je pokazalo da polimerne trake armirane ugljičnim vlaknima s jednoslojnim zidom od pune opeke tvore izrazito otporan konstrukcijski element [12].

Tri su panela Soligno građevine ispitana pod dijagonalnim tlakom. Prvo je jedan panel ispitan neojačan, zatim je obnovljen tehnikom injektiranja, nakon čega je ponovno ispitan. Drugi je panel ispitan ojačan polimernim trakama s karbonskim vlaknima. Kod panela ojačanog tehnikom injektiranja ${ }_{2}$ prijelomno naprezanje pokazalo se $145 \%$ većim nego kod neojačanog panela, a i posmična čvrstoća pokazala je ekstremno povećanje. Panel ojačan polimernim trakama pokazao je 140--postotno povećanje prijelomnog naprezanja i 110--postotno povećanje posmične čvrstoće u odnosu na neojačani panel (tablica 6). Slom panela dogodio se odvajanjem slojeva kamenog ziđa [12]. 
Tablica 6 - Rezultati ispitivanja panela dijagonalnim tlakom [12]

\begin{tabular}{|l|l|c|c|c|c|c|}
\hline \multicolumn{1}{|c|}{ Panel građevine } & \multicolumn{1}{|c|}{ Tehnika ojačanja } & $\begin{array}{c}\text { Širina } \\
(\mathbf{c m})\end{array}$ & $\begin{array}{c}\mathbf{P}_{\max } \\
(\mathbf{k N})\end{array}$ & $\begin{array}{c}\mathbf{T}_{\mathbf{k}} \\
(\mathbf{M P a})\end{array}$ & $\begin{array}{c}\mathbf{G}_{1 / 3} \\
(\mathbf{M P a})\end{array}$ & $\begin{array}{c}\text { Kutna deform. } \\
\mathbf{V}_{1 / 3}\end{array}$ \\
\hline \hline Belfiore & Bez ojačanja & 48 & 34,31 & 0,069 & 131 & 0,136 \\
\hline Belfiore & Polimeri s ugljičnim vlaknima & 48 & 188,25 & 0,373 & 100 & 1,240 \\
\hline Soligno & Bez ojačanja & 57 & 51,14 & 0,053 & 26 & 0,643 \\
\hline Soligno & Injektiranje & 57 & 124,53 & 0,129 & 685 & 0,061 \\
\hline Soligno & Polimeri s ugljičnim vlaknima & 57 & 121,53 & 0,127 & 55 & 0,699 \\
\hline Ponte Postignano & Bez ojačanja & 48 & 47,66 & 0,059 & 37 & 0,533 \\
\hline Ponte Postignano & Injektiranje i zapunjavanje & 48 & 127.71 & 0,157 & 731 & 0,070 \\
\hline Ponte Postignano & Polimeri s ugljičnim vlaknima & 48 & 141,61 & 0,173 & 117 & 0,479 \\
\hline
\end{tabular}

Na građevini Ponte Postignano ispitana su tri panela za tri različita stanja: bez ojačanja, panel ojačan tehnikom injektiranja i zapunjavanja te neoštećeni panel ojačan polimernim trakama $s$ ugljičnim vlaknima. Rezultati ispitivanja u tablici 6 pokazuju značajno povećanje vrijednosti naprezanja i posmične čvrstoće. Slom panela građevine Ponte Postignano nastupio je pri odvajanju slojeva kamenog ziđa [12].

\subsubsection{Analiza krutosti panela}

Ispitivanjem su dobiveni rezultati modula elastičnosti za pojedine slučajeve građevina i tipove ojačanja. Povećanje modula elastičnosti kod panela koji su bili ojačani polimernim trakama kreće se od 200 do $280 \%$ (tablica 7). Tehnika ojačanja injektiranjem dala je slične rezultate vezane za čvrstoću, dok su se rezultati modula elastičnosti pokazali različitima u odnosu na tip ziđa i njegovu teksturu. Kod panela građevine Vescio nije postignuto značajnije povećanje čvrstoće i krutosti, dok su paneli Ponte Postignano, ojačani istom tehnikom, dali vrlo veliko povećanje modula elastičnosti. Ovakve velike oscilacije u rezultatima dovode do zaključka da je za tehniku ojačanja injektiranjem potrebna prethodna analiza ziđa i njegovih značajki. istog. Paneli ojačani polimerima nisu pokazali veće priraste vrijednosti za posmični modul elastičnosti $\mathrm{G}$ u usporedbi s panelima ojačanim tehnikom injektiranja (tablica 7).

\section{Tablica 7 - Rezultati ispitivanja panela na tlak [12]}

\begin{tabular}{|c|c|c|c|c|c|c|c|}
\hline Panel građevine & Tehnika ojačanja & $\begin{array}{l}\text { Širina } \\
(\mathrm{cm})\end{array}$ & $\begin{array}{l}P_{\max } \\
(\mathrm{kN})\end{array}$ & $\begin{array}{l}\mathrm{E} \text { (MPa) } \\
\text { 1. ciklus }\end{array}$ & $\begin{array}{l}\mathrm{E} \text { (MPa) } \\
\text { 2. ciklus }\end{array}$ & $\begin{array}{l}\mathrm{E} \text { (MPa) } \\
\text { 3. ciklus }\end{array}$ & $\begin{array}{c}\sigma_{\max } \\
(\mathrm{MPa})\end{array}$ \\
\hline Belfiore & Bez ojačanja & 48 & 136,91 & 917 & 1105 & 1333 & 0,309 \\
\hline Belfiore & $\begin{array}{l}\text { Polimeri s ugljičnim } \\
\text { vlaknima }\end{array}$ & 48 & 136,03 & 2564 & 2898 & 2673 & 0,315 \\
\hline Vescia & $\begin{array}{l}\text { Polimeri sa staklenim } \\
\text { vlaknima }\end{array}$ & 48 & 137,61 & 1959 & 2063 & 1802 & 0,322 \\
\hline Vescia & Injektiranje & 48 & 136,40 & 1814 & 1644 & 1652 & 0,305 \\
\hline Ponte Postignano & Bez ojačanja & 48 & 92,19 & 471 & 766 & 415 & 0,218 \\
\hline Ponte Postignano & Injektiranje & 48 & 142,20 & 2107 & 2024 & 1862 & 0,337 \\
\hline
\end{tabular}

$\mathrm{U}$ odnosu na prirast vrijednosti krutosti, paneli su pokazali povećanje od $250 \%$, dok je kod jednog panela prirast bio zanemariv. Kompozitni polimeri ne mijenjaju statičku shemu konstrukcije niti uzrokuju znatnu razdiobu krutosti, već povećavaju posmičnu čvrstoću ziđa [12]. 


\section{Zaključak}

Pri obnovi povijesnih građevina, koje su većinom zidane-građevine, potrebno je poštovati estetske, povijesne i kulturne zahtjeve te zadovoljiti kriterije protupotresne otpornosti. Ojačanja zidanih konstrukcija proizvodima od kompozitnih polimera u eksperimentalnim laboratorijskim te in situ ispitivanjima pokazala su, u odnosu na tradicionalne tehnike ojačanja, sljedeće prednosti:

- mala ili nikakva dodatna težina;

- brza i neinvazivna primjena koja ne uzrokuje promjene izgleda građevine i ne remeti uporabu iste tijekom izvođenja ojačanja;

- značajna povećanja naprezanja, vlačne i posmične čvrstoće, te

- mogućnost da se izbjegne mehanizam sloma nastajanjem pukotine uzduž tlačne dijagonale.

Navedene prednosti dokazuju učinkovitost kompozitnih polimera pri ojačanju zidanih konstrukcija i potresnoj obnovi istih.

\section{Literatura}

[1] Aničić D.; 1999: Hrvatski i europski pristup potresnoj otpornosti nepokretnih kulturnih dobara, Građevinar,Volume 52, pp 1-7

[2] ElGawady M; Lestuzzi P; Badoux M. 2004: A review of conventional seismic retrofitting techniques for URM. 13th International brick and block masonry conference Amsterdam

[3] Tomaževič M. 2000: Protupotresna obnova postojećih zidanih građevina, Građevinar, Volume 52, Issue 11, pp 683-693

[4] ACl 440R-07, 2007: Report on Fiber-Reinforced Polymer (FRP) Reinforcement for Concrete Structures, ACl Committee 440, American Concrete Institute, Farmington Hills, Mich.

[5] Mair R. I. 1999: Fibre Reinforced Polymers - From Aerospace to Infrastructure, IATSE (Australian Academy of Technological Sciences and Engineering) Focus, Volume 107, pp 5-6

[6] Beslać J.; Bjegović D.; Rosković R. 2005: Inovativni materijali i tehnologije u građenju i održavanju betonskih konstrukcija, Građevinar, Volume 57, Issue 4, pp 247-255.

[7] Kišiček T., Sorić Z., Rak M. 2007: Ispitivanje greda i ploča armiranih šipkama od PAV-a, Građevinar, Volume 59, Issue 7, pp 581-595.

[8] Shrive N.G.;Masia M.J.,Lissel S.L. 2001: Strengthening and rehabilitation of masonry using fibre reinforced, Historical Constructions, P.B. Lourenço, P. Roca (Eds.), Guimarães,

[9] Eshani M.R.; Saadatmanesh H.; Velazquez-Dimas J. 1998: Retrofit of clay brick walls with fiber composites, $11^{\text {th }}$ European Conference on Earthquake Engineering, Balkema, Rotterdam, ISBN 9054109823

[10] Galić J, Sorić Z, Rak M. 2007: Ojačavanje posmično opterećenih zidanih zidova. Građevinar, Volume 59, Issue 4, pp 289-299

[11] Bastianini F.; Corradi M.; Borri A.; Tommaso A. 2005: Retrofit and monitoring of an historical building using "Smart"CFRP with embedded fibre optic Brillouin sensors, Construction and building materials, Volume 19, pp 525-535

[12] Corradia M.; Borria A.; Vignolib A. 2002: Strengthening techniques tested on masonry structures struck by the Umbria-Marche earthquake of 1997-1998; Construction and building materials, Volume 16, pp 229-239 